Review

\title{
Biphasic Functions of Sodium Fluoride (NaF) in Soft and in Hard Periodontal Tissues
}

\author{
Xingzhi Wang ${ }^{1,+} \mathbb{D}^{\mathbb{D}}$, Nitesh Tewari ${ }^{2,+} \mathbb{D}$, Fuyuki Sato ${ }^{3} \mathbb{D}$, Keiji Tanimoto ${ }^{4}$, , Lakshmi Thangavelu ${ }^{5}$, \\ Makoto Makishima ${ }^{1, *(D)}$ and Ujjal K. Bhawal ${ }^{5,6, * \mathbb{D}}$
}

check for updates

Citation: Wang, X.; Tewari, N.; Sato, F.; Tanimoto, K.; Thangavelu, L.; Makishima, M.; Bhawal, U.K Biphasic Functions of Sodium Fluoride (NaF) in Soft and in Hard Periodontal Tissues. Int. J. Mol. Sci. 2022, 23, 962. https://doi.org/ $10.3390 /$ ijms23020962

Academic Editor: Maurizio Battino

Received: 20 December 2021

Accepted: 13 January 2022

Published: 16 January 2022

Publisher's Note: MDPI stays neutral with regard to jurisdictional claims in published maps and institutional affiliations.

Copyright: (C) 2022 by the authors. Licensee MDPI, Basel, Switzerland. This article is an open access article distributed under the terms and conditions of the Creative Commons Attribution (CC BY) license (https:// creativecommons.org/licenses/by/ $4.0 /)$.
1 Department of Biochemistry, Nihon University School of Medicine, Tokyo 173-8610, Japan; wangxingzhi1234@outlook.com

2 Centre for Dental Education and Research, Division of Pedodontics and Preventive Dentistry, All India Institute of Medical Sciences, New Delhi 110029, India; dr.nitesht@gmail.com

3 Shizuoka Cancer Center, Pathology Division, Shizuoka 411-8777, Japan; fsatodec1dec2@yahoo.co.jp

4 Department of Translational Cancer Research, Research Institute for Radiation Biology and Medicine, Hiroshima University, Hiroshima 734-8553, Japan; ktanimo@hiroshima-u.ac.jp

5 Center for Transdisciplinary Research, Department of Pharmacology, Saveetha Dental College, Saveetha Institute of Medical and Technical Sciences, Chennai 600077, India; lakshmi@saveetha.com

6 Department of Biochemistry and Molecular Biology, Nihon University School of Dentistry at Matsudo, Chiba 271-8587, Japan

* Correspondence: makishima.makoto@nihon-u.ac.jp (M.M.); bhawal.ujjal.kumar@nihon-u.ac.jp (U.K.B.)

+ These authors are contributed equally to this work.

\begin{abstract}
Sodium fluoride $(\mathrm{NaF})$ is widely used in clinical dentistry. However, the administration of high or low concentrations of $\mathrm{NaF}$ has various functions in different tissues. Understanding the mechanisms of the different effects of $\mathrm{NaF}$ will help to optimize its use in clinical applications. Studies of $\mathrm{NaF}$ and epithelial cells, osteoblasts, osteoclasts, and periodontal cells have suggested the significant roles of fluoride treatment. In this review, we summarize recent studies on the biphasic functions of $\mathrm{NaF}$ that are related to both soft and hard periodontal tissues, multiple diseases, and clinical dentistry.
\end{abstract}

Keywords: fluoride; epithelial cells; mesenchymal stem cells; osteoblasts; osteoclasts; periodontal disease; miRNA

\section{Introduction}

Fluoride is well known for its use in the treatment of dental caries, either systemically or topically [1]. Fluoride intake (such as in drinking water, fluoridated toothpaste, or fluoride supplements) is the cornerstone to preventing dental caries in adults and children. Fluoride prevents dental caries by slowing down the demineralization of enamel, which is caused by the interaction between dental plaque and dental hard tissues. Fluoride may inhibit tooth decay by $40-60 \%$ by co-precipitating calcium and phosphate ions and by enhancing the precipitation of fluoridated apatite. Fluoride is also found deposited as calcium fluoride in dental plaque, which helps to prevent dental caries [2]. However, a high concentration of fluoride alters the mineralization process and can cause hypomineralization or fluorosis [3]. It has been demonstrated that a concentration of fluoride between 1.6 and $1.8 \mathrm{ppm}$ in the drinking water is the risk threshold for dental fluorosis [4]. Osteoporosis and osteosclerosis are induced by high concentrations of sodium fluoride $(\mathrm{NaF})$ in the drinking water [5]. Genotoxicity has been found to be related to oxidative stress or cell cycle disturbances induced by high concentrations of fluoride [6].

The effects of fluoride are biphasic. Exposing human dental pulp cells to a low concentration of $\mathrm{NaF}(25 \mu \mathrm{M}-50 \mu \mathrm{M})$ stimulated proliferation and differentiation, while a concentration of $\mathrm{NaF}$ at $50 \mu \mathrm{M}$ to $100 \mu \mathrm{M}$ stimulated proliferation, differentiation, and collagen synthesis in human osteoblastic osteosarcoma cells [7]. Myoblasts exposed to 
low concentrations of $\mathrm{NaF}$ promoted proliferation, which could be regarded as a muscle enhancing factor, and high concentrations elevated the expression of muscle atrophyrelated genes, myostatin and atrogin-1, reactive oxygen species (ROS), and inflammatory factors that accelerate skeletal muscle atrophy [8]. Fluoride can alter the bone mineral metabolism and can affect the homeostasis of bone formation and resorption [9]. Early studies demonstrated that the intake of fluoridated water can inhibit hydrocortisoneinduced bone resorption and parathormone-induced alveolar bone resorption [10,11] Using fluoride as a therapeutic agent to treat postmenopausal osteoporosis in adults has also been investigated [12].

High and low concentrations of fluoride result in toxic or tolerated dosages, respectively, making it vital to determine the concentration of fluoride intake. Various signaling pathways can alter cellular or metabolic actions in response to either high or low concentrations of fluoride. This review focuses on the various effects induced by high and low concentrations of fluoride.

\section{Fluoride and Epithelial Cells}

Epithelial cells function as a barrier to protect organisms from physical, chemical, and microbial damage and to maintain mucosal integrity [13]. Dental epithelial cells can differentiate into various types of cells that can secrete enamel matrix proteins during tooth development [14]. The matrix metalloproteinase-20 (MMP-20) is produced by ameloblasts and is responsible for cleaving other enamel matrix proteins such as amelogenin, ameloblastin, and enamelin [15]. MMP-20 is produced at the secretory stage of dental enamel formation and cleaves proteins that allow the crystals to grow into the space [15]. Ameloblasts also secrete kallikrein-4 (KLK4), which is essential for the breakdown of enamel proteins and enamel crystallization [16]. KLK4 helps crystals to grow and contract, which strengthens the enamel at the last stage of amelogenesis [16].

Recent studies have revealed that different concentrations of fluoride have various effects on epithelial cells.

\subsection{High Concentration Fluoride and Epithelial Cells}

A high concentration of $\mathrm{NaF}$ (millimolar level) induces endoplasmic reticulum stress, apoptosis, and DNA fragmentation and interferes with enamel proteinases [17]. Exposure to a high concentration of fluoride results in enamel hypomineralization, also known as enamel fluorosis [18]. The severity of enamel fluorosis increases depending on the volume of fluoride intake and the duration of fluoride exposure [18]. Fluoride decreases the abilities of proteinases such as MMP-20 and KLK4 that degrade enamel matrix proteins, and as a result, inhibits crystal growth [19]. Alternatively, the intake of fluoride lowers the $\mathrm{pH}$, which inhibits the synthesis and secretion of KLK4 [20]. One study reported that excessive fluoride results in hypomineralization through the reduced expression of Forkhead box O1 (FOXO1) in dental epithelial cells [21]. FOXO1 is reduced after exposure to excessive fluoride, which might affect the expressions of KLK4 and amelotin (AMTN), which ultimately results in enamel fluorosis. One $\mathrm{mM}$ fluoride was found to be cytotoxic and induced apoptosis in human gingival epithelial cells. Treatment with $2 \mathrm{mM} \mathrm{NaF}$ disturbed the gene network accompanied by endoplasmic reticulum stress [22].

\subsection{Low Concentration Fluoride and Epithelial Cells}

Studies have shown that fluoride has biphasic effects on epithelial ameloblast-lineage cells at different concentrations. Reduced proliferation was observed at a fluoride concentration higher than $1 \mathrm{mM}$; however, lower concentrations of fluoride, e.g., around $16 \mu \mathrm{M}$, promoted the proliferation of epithelial ameloblast-lineage cells [23].

During gingival wound healing, human epithelial cells cover the wound, a process termed re-epithelialization. The process of wound healing includes epithelial cell proliferation and migration as well as the synthesis and deposition of extracellular matrix components [24]. Extracellular matrix proteins such as fibronectin and laminin-5 are expressed 
by migrating keratinocytes during wound healing. To understand the characteristics of gingival epithelial cells responding to fluoride, human primary epithelial cells were treated with $\mathrm{NaF}$ to characterize their effects on cellular physiology. Cell proliferation peaked at a concentration of $50 \mu \mathrm{M}$ of $\mathrm{NaF}$, and a higher concentration of $\mathrm{NaF}$ (at the millimolar level) reduced proliferation. Cells treated with $50 \mu \mathrm{M}$ of NaF showed significantly more motility than non-treated cells in vitro. qRT-PCR analyses showed increased mRNA expression levels of fibronectin and laminin-5 in cells treated with $50 \mu \mathrm{M}$ of $\mathrm{NaF}$ [25].

\subsection{Fluoride and Epithelial-Mesenchymal Interactions}

Epithelial-mesenchymal interactions (EMT) are important for the development of ectodermal organs and for tissue regeneration and wound healing, including cellular events such as cell adhesion, proliferation, differentiation, and maturation [26]. Homeostasis, inflammation, migration and proliferation, and remodeling are the four major processes of wound healing [27]. Fibroblast growth factor 2 (FGF2) and its receptor, fibroblast growth factor receptor 2 (FGFR2), are crucial for proliferation, migration, and protease production in epithelial cells [28]. FGF2 is associated with EMT by inducing mesenchymal characteristics in epithelial cells [29]. Fibroblast growth factor 7 (FGF7) is essential for epithelial morphogenesis [30]. Twist family BHLH transcription factor 1 (Twist1) is a critical mediator for EMT [31]. One study demonstrated that treatment with $50 \mu \mathrm{M}$ of $\mathrm{NaF}$ induces the expression of FGF2 and FGF7, and Twist1 is also upregulated in vivo. It was also found that the untreated group had more persistent wounds in mice [32].

\section{Fluoride and Bone Marrow Mesenchymal Stem Cells (BMMSCs)}

BMMSCs present in the bone marrow are self-renewing precursor cells that have the multipotency to differentiate into osteoblasts, chondroblasts, adipoblasts, and stromal cells [33]. Upon bone injuries, BMMSCs differentiate into osteoblasts and release growth factors during wound healing [34]. Consistent with other studies, fluoride also has dual effects on BMMSCs. A low concentration of $\mathrm{NaF}(50$ or $500 \mu \mathrm{M})$ enhanced the proliferation of BMMSCs, while a high concentration of $\mathrm{NaF}(5 \mathrm{mM})$ reduced their proliferation. Furthermore, BMMSCs showed elevated motility and migration when compared with the control group. Treatment with $50 \mu \mathrm{M}$ of $\mathrm{NaF}$ upregulated the expression of fibronectin and vimentin, which induced the Runt-related transcription factor (Runx2), induced osteoblast differentiation, and increased the secretion of osteocalcin (OCN) [35]. Treatment with a higher concentration of $\mathrm{NaF}$ induced cytotoxicity, DNA damage, and oxidative stress in BMMSCs [36]. Studies have indicated that fluoride-induced cytotoxicity depends on the concentration and the duration of fluoride exposure [37]. High concentrations of $\mathrm{NaF}$ ( $2 \mathrm{mM}$ and above) result in oxidative stress and decreased viability and proliferation via the phosphor-c-Jun N-terminal kinase (JNK) pathway. In dental pulp stem cells, a low concentration of $\mathrm{NaF}$ promotes osteo/odontogenic differentiation via the PI3K/Akt pathway [38]. In addition, a low concentration of NAF $(0.5 \mathrm{mM})$ is the optimal concentration to regulate the osteo/odontogenic differentiation of stem cells from apical papilla [39]. When exposed to mouse embryonic stem cells, a high concentration of $\mathrm{NaF}$ (over $1 \mathrm{mM}$ ) induced ROS and reduced DNA synthesis, which resulted in apoptosis through a JNK-dependent pathway [40].

\section{Fluoride and Bone Metabolism}

Bone homeostasis is maintained through bone formation by osteoblasts and bone resorption by osteoclasts [41]. The activity of osteoblasts and osteoclasts is critical for bone maintenance and remodeling. The process is regulated by many factors, such as sex hormones, parathyroid hormones, and calcitonin, as well as various growth factors and cytokines [42]. Osteoblasts and osteoclasts also can control each other's formation, differentiation, apoptosis through multiple pathways via cytokines, extracellular proteins, and transcription factors [43]. Bone diseases such as osteoporosis are caused by dysfunc- 
tional bone remodeling or the disruption of the homeostasis maintained by osteoblasts and osteoclasts [43].

Both positive and negative effects of fluoride on bones and teeth have been well established $[44,45]$. Fluoride treatment increases the proliferation of osteoblasts and inhibits the function of osteoclasts [46]. Trace amounts of fluoride have been used to treat osteoporosis, vertebral fractures, and bone loss in patients [47], whereas excessive fluoride results in skeletal fluorosis [48]. Long-term exposure to fluoride can result in skeletal and dental fluorosis [49]. Thus, a better understanding of the effects of different concentrations of $\mathrm{NaF}$ on bone homeostasis will help to gain more insights into the usage of fluoride.

\subsection{Fluoride and Osteoblasts}

OCN and Osteopontin (OPN) are non-collagenous proteins secreted by osteoblasts that serve as markers for osteoblast maturation [50]. OCN promotes bone formation and regulates mineralization in the bone matrix, which has a complex regulatory network [51]. OPN is an extracellular matrix protein that has multiple functions associated with bone structuring and destruction in osseous tissues [52]. The transcription factor Runx2 induces the expression of osteoblastic genes including OCN and OPN [53]. Runx2 is expressed at different stages of osteoblasts (pre-osteoblasts, and immature and mature osteoblasts) and is essential for bone formation and osteoblastic differentiation [54]. Osterix (OSX), a zinc-finger containing a transcription factor, is also a downstream target of Runx2 [55]. Together with Runx2, OSX regulates the differentiation of pre-osteoblasts into mature osteoblasts and osteocytes, and the roles of OSX in maintaining bone homeostasis have been well studied [37]. One study showed that $\mathrm{NaF}$ treatment affects calcium homeostasis and transcription factor expression [56]. A low concentration of NaF induced Runx2 and OSX while a high concentration of NaF reduced their expression both at the mRNA and protein levels. Treatment of MC3T3-E1 cells with 50 or $500 \mu \mathrm{M}$ of NaF enhanced their proliferation, alkaline phosphatase (ALP) activity, and extracellular matrix mineralization, as well as their expression of bone-related genes (Runx2, OSX, OCN, and OPN) [57]. Different concentrations of $\mathrm{NaF}$ were also found to differentially affect the expression of bone mineralized regulator proteins, such as OCN, OPN, osteonectin (ON), and bone sialoprotein (BSP) in bone marrow stromal cells. A higher concentration of $\mathrm{NaF}\left(10^{-5} \mathrm{M}\right)$ decreased the level of the proteins while a lower concentration $\left(10^{-7} \mathrm{M}\right)$ increased them [44].

Various cellular mechanisms, including the Mitogen-activated protein kinase (MAPK) pathway, are proposed to function in bone formation during fluoride treatment [58]. It is well established that a low concentration of $\mathrm{NaF}$ (micromolar levels) regulates tyrosine kinase and ALP activity to increase osteoblast proliferation $[59,60]$. Fluoride treatment of osteoblasts is also biphasic in that low concentrations promote proliferation, whereas higher concentrations result in signs of weakened osteoblast activity [61]. Long periods of fluoride exposure reduce the expression of bcl-2 family proteins, which promotes apoptosis in osteoblastic cells [62]. Fluoride induces mitochondrial respiratory chain complex abnormal expressions, which in turn cause oxidative stress and result in apoptosis [63]. High concentrations of $\mathrm{NaF}$ also regulate the proliferation and cell cycle of the p16 gene methylation during the development of skeletal fluorosis [64]. The schematic diagram shown in Figure 1 summarizes the functions of $\mathrm{NaF}$ in osteoblasts. 


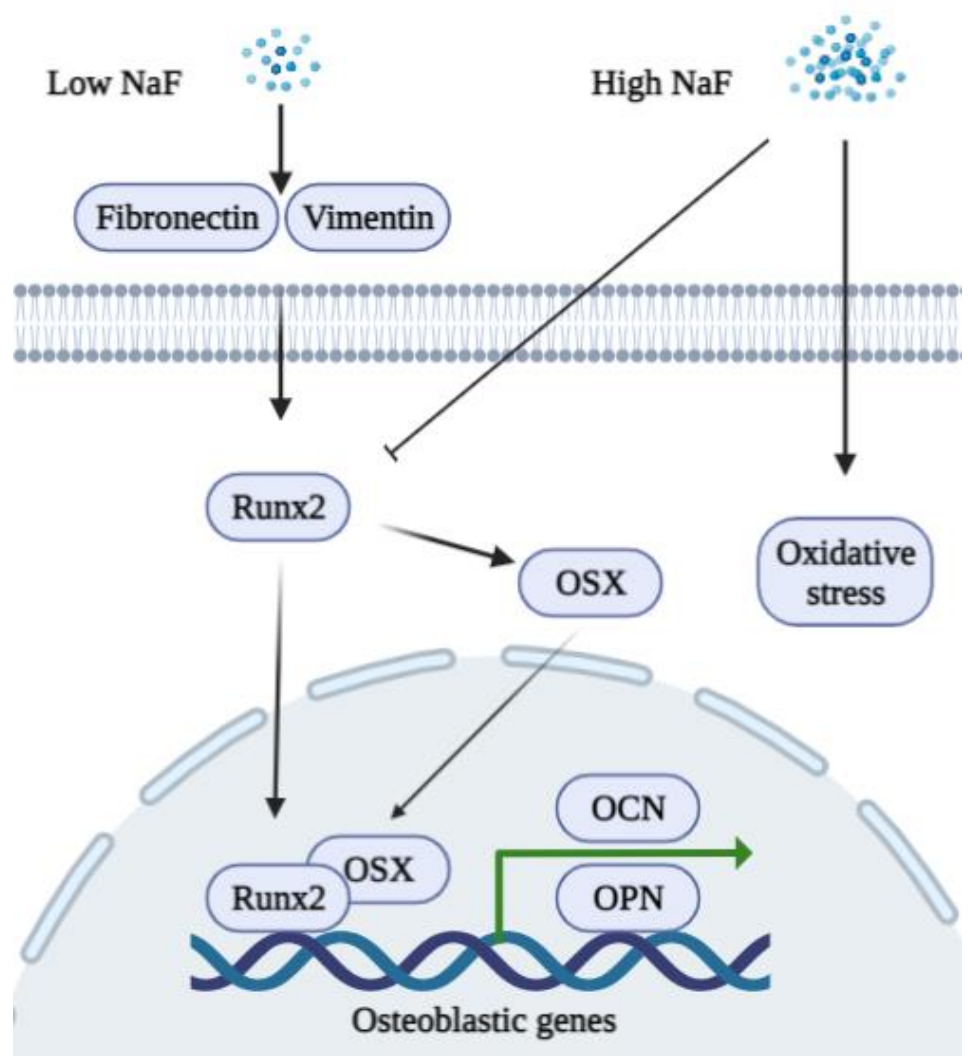

Figure 1. A schematic diagram of the biphasic functions of fluoride in osteoblasts. A low concentration of $\mathrm{NaF}$ stimulates the expression of fibronectin, vimentin, Runx2, and OSX to promote the expression of osteoblastic genes (OCN and OPN). A high concentration of NaF inhibits Runx2 and induces oxidative stress in osteoblasts.

\subsection{Fluoride and Osteoclasts}

Osteoprotegerin (OPG) is a soluble cytokine receptor of the tumor necrosis factor (TNF) receptor family that binds to the OPG ligand [65]. The receptor activator of nuclear factor kappa-B ligand (RANKL) is also a member of the TNF superfamily, which binds to RANK on target cells. OPG/RANKL/RANK is a key signaling pathway in bone metabolism. The overexpression of OPG alters osteoclast differentiation, and recombinant OPG impedes ovariectomy-induced bone loss in rats [66]. Recombinant OPG binds to OPG ligand on BMMSCs, thereby inhibiting osteoclast differentiation [67]. RANKL is an essential cytokine that regulates osteoclastogenesis and bone resorption [68]. In response to RANKL activation, the nuclear factor of activated T cells 1 (NFATc1) regulates the terminal differentiation of osteoclasts, and NFATc1-deficient embryonic stem cells were unable to differentiate into osteoclasts [69]. NFATc1 participates in the transcription of the genes involved in heart/valve septum formation, angiogenesis, T cell proliferation, and osteoclast formation. NFATc1 binds to the promoter of genes associated with bone resorption, including cathepsin K and matrix metalloproteinase 9 (MMP-9), thus inducing their gene expression [70].

Low concentrations of $\mathrm{NaF}$ (micromolar level) have little influence on the viability of BMMSCs and significantly downregulate both mRNA and the protein expression levels of NFATc1 in rat osteoclasts, which result in a reduction in the levels of cathepsin K and the attenuation of bone destruction [71]. Treatment with $0.5 \mathrm{mM}$ to $1 \mathrm{mM}$ of NaF inhibits the activity of osteoclasts in vitro [72]. Studies suggest that fluoride can act on matrix proteinases such as Metalloproteinases-2 and -9, thus inhibiting the matrix degradation [73,74]. Low concentrations of fluoride can possibly regulate osteoclasts via the B lymphocyte-induced maturation protein-1 (Blimp1)/B cell lymphoma 6 (Bcl6) axis which is a critical signaling 
pathway that regulates osteoclast differentiation and bone homeostasis [75]. On the other hand, the stimulation of $\mathrm{NaF}$ exhibits a U-shaped curve in a dose-dependent manner [76]. High concentrations of NaF induce RANKL and decrease OPG, thus increasing osteocytedriven osteoclastogenesis via the RANK-JNK-NFATc1 signaling pathway [77]. A recent study found that osteoclasts demonstrate the most sensitivity to high concentrations of $\mathrm{NaF}$ with respect to other bone cell types and that fluoride exposure induces apoptosis via the Transforming growth factor (TGF)- $\beta$ signaling pathway [78]. A schematic diagram of the functions of $\mathrm{NaF}$ in osteoclasts is shown in Figure 2.

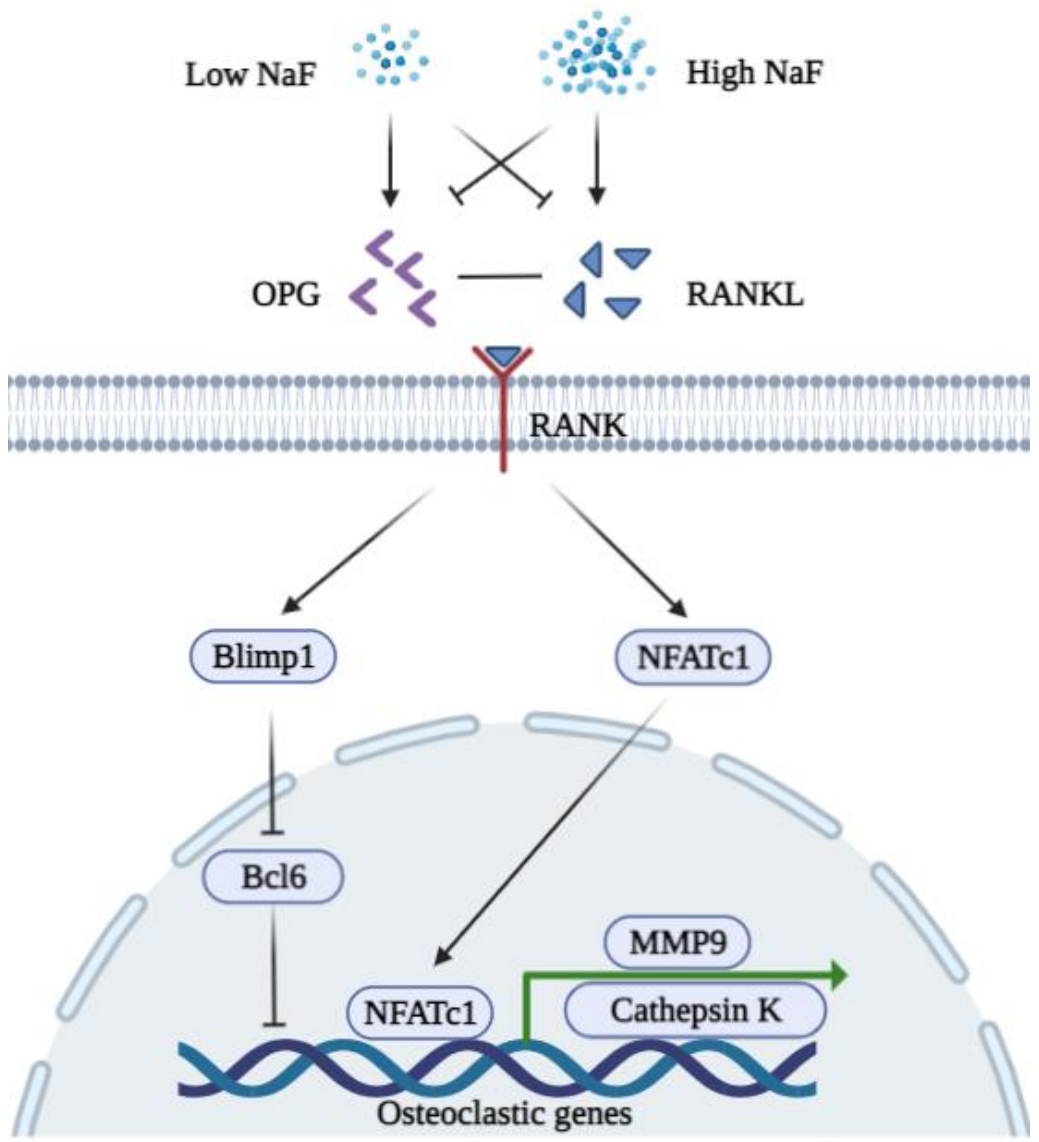

Figure 2. A schematic diagram of the biphasic functions of fluoride in osteoclasts. A low concentration of NaF inhibits the expression of RANKL, NFATc1, MMP9, and Cathepsin K but induces OPG to bind RANKL. A low concentration of NaF is possibly associated with Blimp1/Bcl6 to repress the expression of osteoclastic genes (MMP9 and Cathepsin K). A high concentration of NaF decreases the expression of OPG while inducing RANKL to bind RANK. Induced NFATc1 translocate into the nucleus to promote osteoclastogenesis.

\section{Fluoride and Periodontal Diseases}

Periodontal diseases are induced by bacterial biofilms caused by Gram-negative anaerobic bacteria [79]. Dental plaque formed after bacteria colonize teeth stimulates the host's inflammation responses in gingival connective tissues [80,81]. Chronic periodontitis is mediated by interactions between the host and pathogens, which result in the apical migration of epithelial attachment and ultimately the destruction of connective tissue and alveolar bone [82,83].

A low concentration of $\mathrm{NaF}$ had anti-inflammatory effects that decreased the expression of IL-1 $\beta$, IL-8, and TNF- $\alpha$ in human gingival fibroblasts [84]. A recent study demonstrated that $\mathrm{NaF}$ has an antibacterial activity against $P$. gingivalis in a concentrationdependent manner. A model of rat periodontitis treated with $500 \mu \mathrm{M}$ of $\mathrm{NaF}$ in drinking water showed attenuated alveolar bone resorption and reduced levels of interleukins- 6 
and -8. The expression of NFATc1 was also reduced in osteoclasts and cathepsin K [71]. Another study found that treatment with $\mathrm{NaF}$ could reduce $P$. gingivalis-induced inflammation and bone loss in rat periodontitis tissues and significantly reduce the infiltration of polymorphonuclear leukocytes (PMN) [57].

Diabetes mellitus (DM) is associated with a reduction in insulin production or relative changes that increase glucose levels in the blood during insulin activity [85]. Hyperglycemia induced by increased glucose affects many tissues and organs, such as the kidneys, nerves, blood vessels, and periodontal tissues. Periodontitis is the sixth complication of DM, and they share various pathogenic mechanisms; however, the exact mechanism by which diabetes is associated with periodontitis is not fully understood [86]. One study reported that periodontitis models with diabetes suffer more alveolar bone loss than those without diabetes [87].

Insulin-like growth factors (IGFs) are involved in the development and growth of $\beta$ cells that are important for $\beta$ cells' mitogenic action and inhibit $\beta$ cell apoptosis [88]. The fetal and adult pancreas can produce IGFs and their binding receptors. The overexpression of IGF- 2 causes apoptosis in islets and islet hyperplasia, while increased $\beta$ cell mass elevates IGF-1 expression. The elevation of IGF-1 or mediators in the IFG signaling pathway protects $\beta$ cells from apoptosis, thus preventing diabetes in mice [89-91].

IGFs are autocrine/paracrine factors that regulate the proliferation, differentiation and functions of osteoblasts, osteocytes, and osteoclasts [92,93]. Fluoride is possibly associated with IFG-1 to enhance osteogenic cell proliferation through protein tyrosine phosphorylation $[12,59,61]$. A recent study confirmed that the expression of IGF-1, IFG-2, IFG-1R, and IGF-2R increased after NaF treatment, while the expression of TNF- $\alpha$, IL-1 $\beta$, RANKL, and cathepsin $\mathrm{K}$ decreased. These effects contributed to attenuated alveolar bone resorption caused by a low concentration of $\mathrm{NaF}$ [94].

Autophagy is a cellular process that eliminates damaged proteins and organelles, which is important for maintaining cellular homeostasis [95]. Autophagy-related 5 (ATG5) is essential for forming autophagosomes, and ATG5 knockout in mice results in the dysfunction of autophagy and cell death [96]. ATG5 stimulates light chain 3 (LC3)-I and LC3-II and subsequently generates autophagosomes [97]. Beclin-1 helps to recruit ATG proteins and activates downstream genes [98]. Beclin-1 is regarded as an inter-mediator between apoptosis and autophagy, and the dysfunction of autophagy could result in excessive apoptosis [99].

Accumulating evidence suggests that autophagy has an important role in periodontal inflammation [100]. One study demonstrated that a high concentration of $\mathrm{NaF}$ induces the apoptosis of human cementoblasts through the inhibition of autophagy. Autophagy-related genes ATG5 and Beclin-1 were suppressed, resulting in alveolar bone resorption [101].

A high concentration of $\mathrm{NaF}$ induces oxidative stress, leading to the dysfunction of mitochondria and the stimulation of cell apoptosis [102,103]. Autophagy may serve a protective role in response to fluoride-induced oxidative damage, and the impairment of autophagy results in excessive apoptosis [104,105]. A low concentration of $\mathrm{NaF}$ facilitated the expression of osteo-/odontogenic markers of apical papilla cells via the enhanced autophagy pathway [39]. Figure 3 summarizes the biphasic functions of fluoride in periodontal inflammation. 


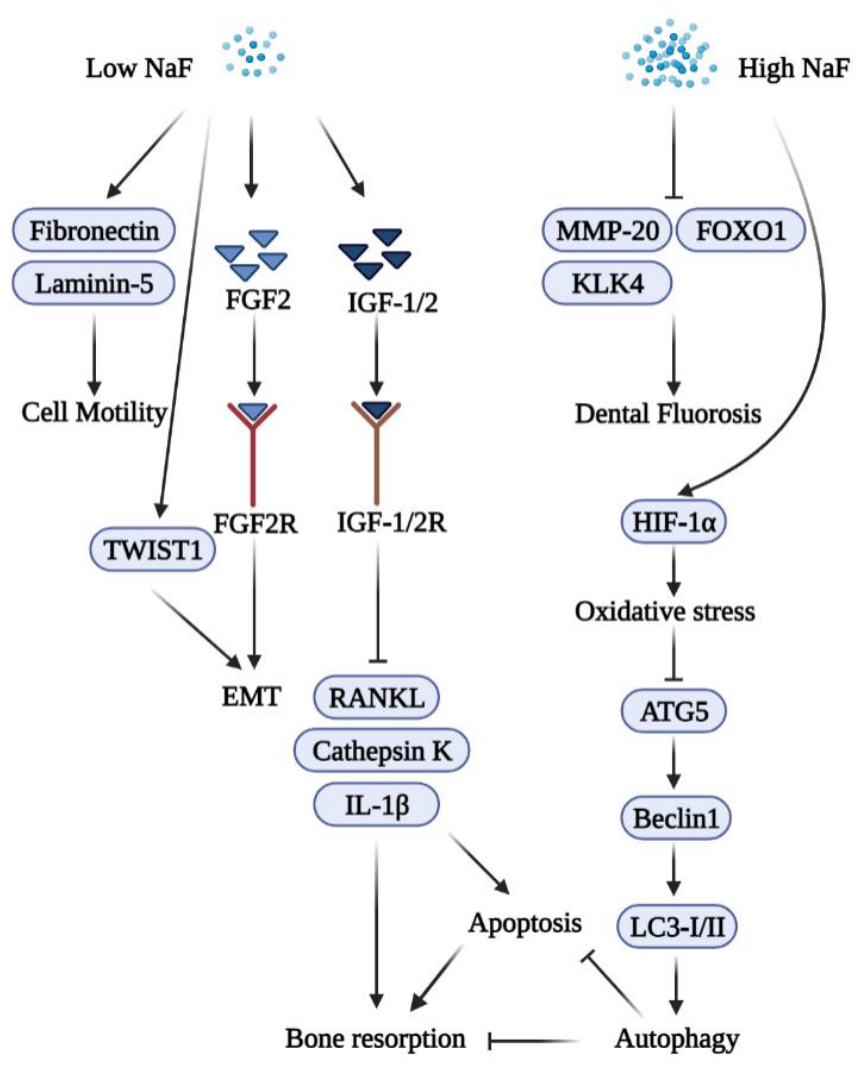

Figure 3. A schematic diagram of the biphasic functions of fluoride in periodontal disease and epithelium cells. A low concentration of $\mathrm{NaF}$ induces fibronectin and laminin-5 to improve wound healing, increases the expression of TWIST1 and FGF2 and its receptor to enhance EMT, and attenuates bone resorption via the induction of IGF-1/2 and their receptors which subsequently suppress RANKL, Cathepsin $\mathrm{K}$, and IL-1 $\beta$. A high concentration of NaF inhibits extracellular matrix proteinases (MMP-20 and KLK4), and FOXO1 results in fluorosis. A high concentration of NaF induces hypoxiainducible factor 1-alpha (HIF-1 $\alpha$ ) and oxidative stress, thus inhibits ATG, Beclin, and LC3-I/II to impair autophagy leading to apoptosis and bone resorption.

\section{Fluoride and microRNA}

Excessive $\mathrm{NaF}$ intake ameliorates dental and skeletal fluorosis. miR-124 and miR-155 are reported to be critical players in fluorosis biology [106]. The recent finding of increased cyclinD1 expression due to miR-486-3p made a significant contribution to understanding the mechanism of skeletal fluorosis [107]. Finding that cyclinD1 is also a direct target of miR-4755-5p, and fluoride exposure suppresses miR-4755-5p and induces cyclinD1 protein in osteoblasts, thus shedding new light upon fluorosis treatment [108]. miR-200c$3 p$ is also considered a potential biomarker for skeletal fluorosis [109]. NaF treatment upregulates miR-200c-3p expression via the BMP4/Smad signaling pathway [109]. NaF exposure mainly affects the Notch, Wnt, hedgehog, and TGF-beta signaling pathways in the osteoblasts [110]. miR-122-5p targets CDK4 protein in NaF-treated human osteoblasts, suggesting its involvement in the etiology of skeletal fluorosis [111]. Skeletal fluorosis may alter the expression level of 10 candidate miRNAs in mouse osteoblast cells through numerous signaling molecules, including autophagy [112]. Female reproductive malfunction could be a result of excessive NaF intake, and the microRNAs (miRNAs) play a substantial role in the regulation of reproduction. A recent study demonstrated that miR-378d was inversely correlated with the autophagy markers under NaF exposure on ovarian cells [113]. Fluoride exposure alters the miR-34 family to orchestrate the downstream signaling molecules in sperm [114]. PIWI-interacting RNAs (piRNAs) are explicitly suggested as candidate biomarkers for fluoride-induced testicular toxicity [115]. Perinatal fluoride exposure can 
lead to learning and memory problems in mouse offspring, at least in part by the alteration of miR-124 and miR-132 upregulation and their targets [116].

\section{Clinical Applications}

Fluoride use in clinical dentistry dates to the 1920s, with the recognition of its ability to prevent dental caries [117]. An interesting simultaneous development was the observation of the harmful effects of fluoride on dental and skeletal fluorosis [117]. These macroscopic presentations were soon deciphered in the form of microscopic and molecular mechanisms and pathways [117]. The major application of low concentrations of fluoride in dentistry have been related to the prevention of dental caries by fluoridation of systemic water, milk, and salt [118]. There is a plethora of literature on this topic with high-quality evidence supporting the efficacy of this paradigm $[117,118]$. Fluoride in sodium and stannous and acidulated phosphate forms has found utility in topical applications [119], which have evolved as solutions, gels, varnishes, and pastes [119]. The most recent innovation is the clinical trials evaluating the preventive effects of Silver Diamine Fluoride (SDF) on caries [120]. SDF has a higher concentration of fluoride and a biocompatible association with silver, which arrests the cariogenic process before cavitation and is currently finding global acceptance in pediatric dentistry [120]. Apart from dental caries, the clinical application of a low concentration of fluoride is used in periodontal tissue regeneration [121,122]. A low concentration of fluoride in the form of sodium fluoride is used in root surface biomodification [121-123]. The cemental surface gets exposed to bacterial toxins and the inflammatory process in periodontitis [123]. The root surface is modified and allows for the attachment of periodontal fibroblasts [123]. Andreasen et al. evaluated the use of $\mathrm{NaF}$ as a root surface biomodification method prior to the replantation of avulsed teeth with an extraoral dry time greater than $60 \mathrm{~min}$ [124]. Those results were further evaluated and replicated by several in vitro and animal experiments and attributed to its actions reducing osteoclastic activity [125-127]. The role of low concentrations of fluoride has also been explored in the management of external inflammatory root resorption $[128,129]$. Clinical studies have found that a low concentration of fluoride treatment elevates bone density [130]. In recent years, the adverse clinical effects of fluoride have warranted a search for viable alternatives. The dental remineralization area had witnessed significant changes with the evolution of Casein Phosphopeptide-Amorphous Calcium Phosphate (CCP-ACP) technology. Subsequently, other molecules, such as Novamin, were included in the index, and most recently, the self-assembling peptides have become the cornerstone of contemporary remineralization paradigms $[131,132]$. Fluoride-free alternatives, including hydroxyapatite, also exhibited beneficial consequences in preventing dental caries, periodontitis, and enamel remineralization and in increasing calcium, phosphorus, and silicon deposition $[133,134]$. Replacing fluoride with these substances might be a solution to avoid the toxicity risk of high concentrations of fluoride.

\section{Discussion}

The application of $\mathrm{NaF}$ in preventing dental caries has been well established. However, both positive and negative effects have been reported. Due to the dual nature of fluoride, it is important to understand the physiology and pathology process during fluoride treatment. Low concentrations of NaF promote wound healing in epithelial cells and BMMSCs. NaF treatment plays crucial roles in maintaining both osteoblasts and osteoclasts, which are important to homeostasis in bone metabolism. An optimal level of NaF could effectively protect against bone resorption. Fluoride consumption affects different types of cells in the body and interferes with various signaling pathways such as inflammation, autophagy, and apoptosis. These advantages of $\mathrm{NaF}$ could be used in clinical treatments for periodontal diseases. In contrast, a high concentration of $\mathrm{NaF}$ results in fluorosis, oxidative stress, DNA damage, and even toxicity. Thus, finding an appropriate concentration is important for $\mathrm{NaF}$ application. Fluoride affects various organs and is implicated in many diseases that have an extensive regulatory network. Exploring the precise mechanisms of the actions of 
fluoride is crucial for clinical applications. Systematic studies of fluoride treatments will provide more insights into therapeutic applications.

Author Contributions: Conceptualization, X.W., N.T., L.T. and U.K.B.; writing-original draft preparation, X.W. and N.T.; writing-review and editing, F.S., K.T., L.T., M.M. and U.K.B.; visualization, X.W.; supervision, M.M. and U.K.B.; project administration, F.S., K.T., M.M. and U.K.B. All authors have read and agreed to the published version of the manuscript.

Funding: This work was supported by Grants-in-Aid from the Ministry of Education, Culture, Sports, Science, and Technology of Japan, Grant No. 15K11433 and No. 16K11898.

Acknowledgments: We thank Toshizo Toyama and Takenori Sato for the P. gingivalis treatment and the staff of the animal facility for care of the mice.

Conflicts of Interest: The authors declare no conflict of interest.

\section{References}

1. Whelton, H.; Spencer, A.; Do, L.; Rugg-Gunn, A. Fluoride Revolution and Dental Caries: Evolution of Policies for Global Use. J. Dent. Res. 2019, 98, 837-846. [CrossRef] [PubMed]

2. Cate, J.T.; Buzalaf, M. Fluoride Mode of Action: Once There Was an Observant Dentist. J. Dent. Res. 2019, 98, 725-730. [CrossRef] [PubMed]

3. DenBesten, P.K. Biological mechanisms of dental fluorosis relevant to the use of fluoride supplements. Community Dent. Oral Epidemiol. 1999, 27, 41-47. [CrossRef]

4. Whitford, G.M. The metabolism and toxicity of fluoride. Monogr. Oral Sci. 1996, 16, 1-153.

5. Gupta, A.R.; Dey, S.; Saini, M.; Swarup, D. Toxic effect of sodium fluoride on hydroxyproline level and expression of collagen-1 gene in rat bone and its amelioration by Tamrindus indica L. fruit pulp extract. Interdiscip. Toxicol. 2016, 9, 12-16. [CrossRef] [PubMed]

6. Ribeiro, D.A.; Yujra, V.Q.; Da Silva, V.H.P.; Claudio, S.R.; Estadella, D.; Viana, M.D.B.; Oshima, C.T.F. Putative mechanisms of genotoxicity induced by fluoride: A comprehensive review. Environ. Sci. Pollut. Res. 2017, 24, 15254-15259. [CrossRef]

7. Shenoy, P.S.; Sen, U.; Kapoor, S.; Ranade, A.V.; Chowdhury, C.R.; Bose, B. Sodium fluoride induced skeletal muscle changes: Degradation of proteins and signaling mechanism. Environ. Pollut. 2018, 244, 534-548. [CrossRef] [PubMed]

8. Nakade, O.; Koyama, H.; Arai, J.; Ariji, H.; Takada, J.; Kaku, T. Stimulation by low concentrations of fluoride of the proliferation and alkaline phosphatase activity of human dental pulp cells in vitro. Arch. Oral Biol. 1999, 44, 89-92. [CrossRef]

9. Boivin, G.; Chavassieux, P.; Chapuy, M.; Baud, C.; Meunier, P. Skeletal fluorosis: Histomorphometric analysis of bone changes and bone fluoride content in 29 patients. Bone 1989, 10, 89-99. [CrossRef]

10. Zipkin, I.; Bernick, S.; Menczel, J.A. Morphological study of the effect of fluoride on the periodontium of the hydrocorti-sonetreated rat. Periodontics 1965, 3, 111-114. [CrossRef]

11. Levy, B.M.; Dreizen, S.; Bernick, S.; Hampton, J.K. Studies on the Biology of the Periodontium of Marmosets: IX. Effect of Parathyroid Hormone on the Alveolar Bone of Marmosets Pretreated with Fluoridated and Nonfluoridated Drinking Water. J. Dent. Res. 1970, 49, 816-821. [CrossRef] [PubMed]

12. Ammann, P.; Rizzoli, R.; Caverzasio, J.; Bonjour, J.-P. Fluoride Potentiates the Osteogenic Effects of IGF-I in Aged Ovariectomized Rats. Bone 1998, 22, 39-43. [CrossRef]

13. Wang, S.-S.; Tang, Y.-L.; Pang, X.; Zheng, M.; Liang, X.-H. The maintenance of an oral epithelial barrier. Life Sci. 2019, 227, 129-136. [CrossRef] [PubMed]

14. Kawano, S.; Saito, M.; Handa, K.; Morotomi, T.; Toyono, T.; Seta, Y.; Nakamura, N.; Uchida, T.; Toyoshima, K.; Ohishi, M.; et al. Characterization of Dental Epithelial Progenitor Cells Derived from Cervical-loop Epithelium in a Rat Lower Incisor. J. Dent. Res. 2004, 83, 129-133. [CrossRef] [PubMed]

15. Crivelini, M.M.; Oliveira, D.T.; De Mesquita, R.A.; De Sousa, S.C.O.M.; Loyola, A.M. Kallikrein 4 and matrix metalloproteinase-20 immunoexpression in malignant, benign and infiltrative odontogenic tumors. J. Oral Maxillofac. Pathol. 2016, 20, $246-251$. [CrossRef]

16. Mu, Y.; Tian, R.; Xiao, L.; Sun, D.; Zhang, Z.; Xu, S.; Yang, G. Molecular Evolution of Tooth-Related Genes Provides New Insights into Dietary Adaptations of Mammals. J. Mol. Evol. 2021, 89, 458-471. [CrossRef] [PubMed]

17. Wei, W.; Gao, Y.; Wang, C.; Zhao, L.; Sun, D. Excessive fluoride induces endoplasmic reticulum stress and interferes enamel proteinases secretion. Environ. Toxicol. 2011, 28, 332-341. [CrossRef] [PubMed]

18. DenBesten, P.K.; Zhu, L.; Li, W.; Tanimoto, K.; Liu, H.; Witkowska, H.E. Fluoride incorporation into apatite crystals delays amelogenin hydrolysis. Eur. J. Oral Sci. 2011, 119, 3-7. [CrossRef]

19. DenBesten, P.K.; Yan, Y.; Featherstone, J.D.B.; Hilton, J.F.; Smith, C.E.; Li, W. Effects of fluoride on rat dental enamel matrix proteinases. Arch. Oral Biol. 2002, 47, 763-770. [CrossRef]

20. Sharma, R.; Tsuchiya, M.; Skobe, Z.; Tannous, B.A.; Bartlett, J.D. The Acid Test of Fluoride: How pH Modulates Toxicity. PLoS ONE 2010, 5, e10895. [CrossRef] 
21. Gao, J.; Ruan, J.; Gao, L. Excessive fluoride reducesFoxolexpression in dental epithelial cells of the rat incisor. Eur. J. Oral Sci. 2014, 122, 317-323. [CrossRef]

22. Zuckerbraun, H.L.; Babich, H.; May, R.; Sinensky, M.C. Triclosan, cytotoxicity, mode of action, and induction of apoptosis in human gingival cells in vitro. Eur. J. Oral Sci. 1998, 106, 628-636. [CrossRef]

23. Yan, Q.; Zhang, Y.; Li, W.; DenBesten, P. Micromolar Fluoride Alters Ameloblast Lineage Cells in vitro. J. Dent. Res. 2007, 86, 336-340. [CrossRef]

24. Jorgensen, S.N.; Sanders, J.R. Mathematical models of wound healing and closure: A comprehensive review. Med. Biol. Eng. Comput. 2015, 54, 1297-1316. [CrossRef] [PubMed]

25. Arakawa, Y.; Bhawal, U.K.; Ikoma, T.; Kimoto, K.; Kuroha, K.; Kubota, T.; Hamada, N.; Kubota, E.; Arakawa, H. Low concentration fluoride stimulates cell motility of epithelial cells in vitro. Biomed. Res. 2009, 30, 271-277. [CrossRef]

26. Wixler, V. The role of FHL2 in wound healing and inflammation. FASEB J. 2019, 33, 7799-7809. [CrossRef] [PubMed]

27. Cho, Y.-D.; Kim, K.-H.; Lee, Y.-M.; Ku, Y.; Seol, Y.-J. Periodontal Wound Healing and Tissue Regeneration: A Narrative Review. Pharmaceuticals 2021, 14, 456. [CrossRef] [PubMed]

28. Mossahebi-Mohammadi, M.; Quan, M.; Zhang, J.-S.; Li, X. FGF Signaling Pathway: A Key Regulator of Stem Cell Pluripotency. Front. Cell Dev. Biol. 2020, 8, 79. [CrossRef]

29. El-Baz, L.M.; Shoukry, N.M.; Hafez, H.S.; Guzy, R.D.; Salem, M.L. Fibroblast Growth Factor 2 Augments Transforming Growth Factor Beta 1 Induced Epithelial-mesenchymal Transition in Lung Cell Culture Model. Iran. J. Allergy Asthma Immunol. 2020, 19, 348-361. [CrossRef]

30. Kinoshita-Ise, M.; Tsukashima, A.; Kinoshita, T.; Yamazaki, Y.; Ohyama, M. Altered FGF expression profile in human scalp-derived fibroblasts upon WNT activation: Implication of their role to provide folliculogenetic microenvironment. Inflamm. Regen. 2020, 40, 1-10. [CrossRef] [PubMed]

31. Meng, J.; Chen, S.; Han, J.-X.; Qian, B.; Wang, X.-R.; Zhong, W.-L.; Qin, Y.; Zhang, H.; Gao, W.-F.; Lei, Y.-Y.; et al. Twist1 Regulates Vimentin through Cul2 Circular RNA to Promote EMT in Hepatocellular Carcinoma. Cancer Res. 2018, 78, 4150-4162. [CrossRef] [PubMed]

32. He, D.; Bhawal, U.K.; Hamada, N.; Kuboyama, N.; Abiko, Y.; Arakawa, H. Low Level Fluoride Stimulates Epithelial-Mesenchymal Interaction in Oral Mucosa. J. Hard Tissue Biol. 2013, 22, 59-66. [CrossRef]

33. Chen, F.; Han, Y.; Kang, Y. Bone marrow niches in the regulation of bone metastasis. Br. J. Cancer 2021, 214, 1912-1920. [CrossRef] [PubMed]

34. Zhang, R.; Li, X.; Liu, Y.; Gao, X.; Zhu, T.; Lu, L. Acceleration of Bone Regeneration in Critical-Size Defect Using BMP-9-Loaded nHA/ColI/MWCNTs Scaffolds Seeded with Bone Marrow Mesenchymal Stem Cells. BioMed Res. Int. 2019, $2019,7343957$. [CrossRef]

35. Bhawal, U.K.; Li, X.; Suzuki, M.; Taguchi, C.; Oka, S.; Arikawa, K.; Tewari, N.; Liu, Y. Treatment with low-level sodium fluoride on wound healing and the osteogenic differentiation of bone marrow mesenchymal stem cells. Dent. Traumatol. 2019, 36, 278-284 [CrossRef] [PubMed]

36. Garcia, A.L.; Picinini, J.; Silveira, M.D.; Camassola, M.; Visentim, A.P.; Salvador, M.; da Silva, J. Fluorosilicic acid induces DNA damage and oxidative stress in bone marrow mesenchymal stem cells. Mutat. Res. Toxicol. Environ. Mutagen. 2020, 861-862, 503297. [CrossRef] [PubMed]

37. Fu, X.; Xie, F.-N.; Dong, P.; Li, Q.-C.; Yu, G.-Y.; Xiao, R. High-Dose Fluoride Impairs the Properties of Human Embryonic Stem Cells via JNK Signaling. PLoS ONE 2016, 11, e0148819. [CrossRef]

38. Xu, S.; Xie, X.; Li, C.; Liu, Z.; Zuo, D. Micromolar sodium fluoride promotes osteo/odontogenic differentiation in dental pulp stem cells by inhibiting PI3K/AKT pathway. Arch. Oral Biol. 2021, 131, 105265. [CrossRef]

39. Pan, Y.; Li, Z.; Wang, Y.; Yan, M.; Wu, J.; Beharee, R.G.; Yu, J. Sodium fluoride regulates the osteo/odontogenic differentiation of stem cells from apical papilla by modulating autophagy. J. Cell. Physiol. 2019, 234, 16114-16124. [CrossRef]

40. Ngoc, T.D.N.; Son, Y.-O.; Lim, S.-S.; Shi, X.; Kim, J.-G.; Heo, J.S.; Choe, Y.; Jeon, Y.-M.; Lee, J.-C. Sodium fluoride induces apoptosis in mouse embryonic stem cells through ROS-dependent and caspase- and JNK-mediated pathways. Toxicol. Appl. Pharmacol. 2012, 259, 329-337. [CrossRef] [PubMed]

41. Siddiqui, J.A.; Partridge, N.C. Physiological Bone Remodeling: Systemic Regulation and Growth Factor Involvement. Physiology 2016, 31, 233-245. [CrossRef] [PubMed]

42. Chen, X.; Wang, Z.; Duan, N.; Zhu, G.; Schwarz, E.M.; Xie, C. Osteoblast-osteoclast interactions. Connect. Tissue Res. 2017, 59, 99-107. [CrossRef]

43. Sims, N.A.; Martin, T.J. Osteoclasts Provide Coupling Signals to Osteoblast Lineage Cells Through Multiple Mechanisms. Annu. Rev. Physiol. 2020, 82, 507-529. [CrossRef] [PubMed]

44. Antonarakis, G.S.; Moseley, R.; Waddington, R.J. Differential influence of fluoride concentration on the synthesis of bone matrix glycoproteins within mineralizing bone cellsin vitro. Acta Odontol. Scand. 2014, 72, 1066-1069. [CrossRef] [PubMed]

45. Simon, M.J.K.; Beil, F.T.; Riedel, C.; Lau, G.; Tomsia, A.; Zimmermann, E.A.; Koehne, T.; Ueblacker, P.; Rüther, W.; Pogoda, P.; et al. Deterioration of teeth and alveolar bone loss due to chronic environmental high-level fluoride and low calcium exposure. Clin. Oral Investig. 2016, 20, 2361-2370. [CrossRef] [PubMed]

46. Liu, S.; Zhou, H.; Liu, H.; Ji, H.; Fei, W.; Luo, E. Fluorine-contained hydroxyapatite suppresses bone resorption through inhibiting osteoclasts differentiation and function in vitro and in vivo. Cell Prolif. 2019, 52, e12613. [CrossRef] [PubMed] 
47. Yamaguchi, M. Fluoride and bone metabolism. Clin. Calcium 2007, 17, 217-223.

48. Kurdi, M.S. Chronic fluorosis: The disease and its anaesthetic implications. Indian J. Anaesth. 2016, 60, 157-162. [CrossRef] [PubMed]

49. Qiao, W.; Liu, Q.; Li, Z.; Zhang, H.; Chen, Z. Changes in physicochemical and biological properties of porcine bone derived hydroxyapatite induced by the incorporation of fluoride. Sci. Technol. Adv. Mater. 2017, 18, 110-121. [CrossRef]

50. Epsley, S.; Tadros, S.; Farid, A.; Kargilis, D.; Mehta, S.; Rajapakse, C.S. The Effect of Inflammation on Bone. Front. Physiol. 2021, 11. [CrossRef]

51. Zoch, M.L.; Clemens, T.L.; Riddle, R.C. New insights into the biology of osteocalcin. Bone 2015, 82, 42-49. [CrossRef]

52. Icer, M.A.; Gezmen-Karadag, M. The multiple functions and mechanisms of osteopontin. Clin. Biochem. 2018, 59, 17-24. [CrossRef] [PubMed]

53. Tang, C.-Y.; Wu, M.; Zhao, D.; Edwards, D.; McVicar, A.; Luo, Y.; Zhu, G.; Wang, Y.; Zhou, H.-D.; Chen, W.; et al. Runx1 is a central regulator of osteogenesis for bone homeostasis by orchestrating BMP and WNT signaling pathways. PLoS Genet. 2021, 17, e1009233. [CrossRef]

54. Takahata, Y.; Hagino, H.; Kimura, A.; Urushizaki, M.; Kobayashi, S.; Wakamori, K.; Fujiwara, C.; Nakamura, E.; Yu, K.; Kiyonari, H.; et al. Smoc1 and Smoc2 regulate bone formation as downstream molecules of Runx2. Commun. Biol. 2021, 4, 1-11. [CrossRef] [PubMed]

55. Iaquinta, M.R.; Lanzillotti, C.; Mazziotta, C.; Bononi, I.; Frontini, F.; Mazzoni, E.; Oton-Gonzalez, L.; Rotondo, J.C.; Torreggiani, E.; Tognon, M.; et al. The role of microRNAs in the osteogenic and chondrogenic differentiation of mesenchymal stem cells and bone pathologies. Theranostics 2021, 11, 6573-6591. [CrossRef] [PubMed]

56. Duan, X.-Q.; Zhao, Z.-T.; Zhang, X.-Y.; Wang, Y.; Wang, H.; Liu, D.-W.; Li, G.-S.; Jing, L. Fluoride Affects Calcium Homeostasis and Osteogenic Transcription Factor Expressions Through L-type Calcium Channels in Osteoblast Cell Line. Biol. Trace Element Res. 2014, 162, 219-226. [CrossRef]

57. Lee, M.; Arikawa, K.; Nagahama, F. Micromolar Levels of Sodium Fluoride Promote Osteoblast Differentiation Through Runx2 Signaling. Biol. Trace Element Res. 2017, 178, 283-291. [CrossRef]

58. Volobaev, V.P.; Serdyukova, E.S.; Kalyuzhnaya, E.E.; Schetnikova, E.A.; Korotkova, A.D.; Naik, A.A.; Bach, S.N.; Prosekov, A.Y.; Larionov, A.V. Investigation of the genotoxic effects of fluoride on a bone tissue model. Toxicol. Res. 2020, 36, 337-342. [CrossRef]

59. Burgener, D.; Bonjour, J.-P.; Caverzasio, J. Fluoride increases tyrosine kinase activity in osteoblast-like cells: Regulatory role for the stimulation of cell proliferation and Pi transport across the plasma membrane. J. Bone Miner. Res. 2009, 10, 164-171. [CrossRef]

60. Farley, J.R.; Wergedal, J.E.; Baylink, D.J. Fluoride Directly Stimulates Proliferation and Alkaline Phosphatase Activity of BoneForming Cells. Science 1983, 222, 330-332. [CrossRef]

61. Pak, C.Y.; Zerwekh, J.E.; Antich, P. Anabolic effects of fluoride on bone. Trends Endocrinol. Metab. 1995, 6, 229-234. [CrossRef]

62. Rochette, L.; Meloux, A.; Rigal, E.; Zeller, M.; Cottin, Y.; Vergely, C. The Role of Osteoprotegerin and Its Ligands in Vascular Function. Int. J. Mol. Sci. 2019, 20, 705. [CrossRef]

63. Yang, S.; Wang, Z.; Farquharson, C.; Alkasir, R.; Zahra, M.; Ren, G.; Han, B. Sodium fluoride induces apoptosis and alters bcl-2 family protein expression in MC3T3-E1 osteoblastic cells. Biochem. Biophys. Res. Commun. 2011, 410, 910-915. [CrossRef] [PubMed]

64. Zhao, W.-P.; Wang, H.-W.; Liu, J.; Zhang, Z.-H.; Zhu, S.-Q.; Zhou, B.-H. Mitochondrial respiratory chain complex abnormal expressions and fusion disorder are involved in fluoride-induced mitochondrial dysfunction in ovarian granulosa cells. Chemosphere 2018, 215, 619-625. [CrossRef]

65. Wu, S.; Yan, W.; Qiu, B.; Liao, Y.; Gu, J.; Wei, S.; Zhang, A.; Pan, X. Aberrant methylation-induced dysfunction of p16 is associated with osteoblast activation caused by fluoride. Environ. Toxicol. 2018, 34, 37-47. [CrossRef]

66. Simonet, W.; Lacey, D.; Dunstan, C.; Kelley, M.; Chang, M.-S.; Lüthy, R.; Nguyen, H.; Wooden, S.; Bennett, L.; Boone, T.; et al. Osteoprotegerin: A Novel Secreted Protein Involved in the Regulation of Bone Density. Cell 1997, 89, 309-319. [CrossRef]

67. Usui, M.; Onizuka, S.; Sato, T.; Kokabu, S.; Ariyoshi, W.; Nakashima, K. Mechanism of alveolar bone destruction in periodontitisPeriodontal bacteria and inflammation. Jpn. Dent. Sci. Rev. 2021, 57, 201-208. [CrossRef] [PubMed]

68. McDonald, M.M.; Kim, A.S.; Mulholland, B.S.; Rauner, M. New Insights Into Osteoclast Biology. JBMR Plus 2021, 5, e10539. [CrossRef] [PubMed]

69. Zhao, X.; Patil, S.; Xu, F.; Lin, X.; Qian, A. Role of Biomolecules in Osteoclasts and Their Therapeutic Potential for Osteoporosis Biomolecules 2021, 11, 747. [CrossRef]

70. Kitamura, N.; Kaminuma, O. Isoform-Selective NFAT Inhibitor: Potential Usefulness and Development. Int. J. Mol. Sci. 2021, $22,2725$. [CrossRef]

71. Bhawal, U.K.; Lee, H.-J.; Arikawa, K.; Shimosaka, M.; Suzuki, M.; Toyama, T.; Sato, T.; Kawamata, R.; Taguchi, C.; Hamada, N.; et al. Micromolar sodium fluoride mediates anti-osteoclastogenesis in Porphyromonas gingivalis-induced alveolar bone loss. Int. J. Oral Sci. 2015, 7, 242-249. [CrossRef]

72. Okuda, A.; Kanehisa, J.; Heersche, J.N.M. The effects of sodium fluoride on the resorptive activity of isolated osteoclasts. J. Bone Miner. Res. 2010, 5, S115-S120. [CrossRef] [PubMed]

73. Łukomska, A.; Baranowska-Bosiacka, I.; Dec, K.; Pilutin, A.; Tarnowski, M.; Jakubczyk, K.; Żwierełło, W.; Skórka-Majewicz, M.; Chlubek, D.; Gutowska, I. Changes in Gene and Protein Expression of Metalloproteinase-2 and -9 and their Inhibitors TIMP2 and TIMP3 in Different Parts of Fluoride-Exposed Rat Brain. Int. J. Mol. Sci. 2020, 22, 391. [CrossRef] [PubMed] 
74. Cvikl, B.; Lussi, A.; Carvalho, T.S.; Moritz, A.; Gruber, R. Stannous chloride and stannous fluoride are inhibitors of matrix metalloproteinases. J. Dent. 2018, 78, 51-58. [CrossRef] [PubMed]

75. Miyauchi, Y.; Ninomiya, K.; Miyamoto, H.; Sakamoto, A.; Iwasaki, R.; Hoshi, H.; Miyamoto, K.; Hao, W.; Yoshida, S.; Morioka, H.; et al. The Blimp1-Bcl6 axis is critical to regulate osteoclast differentiation and bone homeostasis. J. Exp. Med. 2010, 207, 751-762. [CrossRef] [PubMed]

76. Yao, Y.; Ma, Y.; Zhong, N.; Pei, J. The Inverted U-Curve Association of Fluoride and Osteoclast Formation in Mice. Biol. Trace Elem. Res. 2019, 191, 419-425. [CrossRef]

77. Jiang, N.; Guo, F.; Xu, W.; Zhang, Z.; Jin, H.; Shi, L.; Zhang, X.; Gao, J.; Xu, H. Effect of fluoride on osteocyte-driven osteoclastic differentiation. Toxicology 2020, 436, 152429. [CrossRef] [PubMed]

78. Jiang, N.; Guo, F.; Sun, B.; Zhang, X.; Xu, H. Different Effects of Fluoride Exposure on the Three Major Bone Cell Types. Biol. Trace Elem. Res. 2019, 193, 226-233. [CrossRef]

79. Haffajee, A.D.; Socransky, S.S. Introduction to microbial aspects of periodontal biofilm communities, development and treatment. Periodontology 2000 2006, 42, 7-12. [CrossRef] [PubMed]

80. Graves, D.; Cochran, D. The Contribution of Interleukin-1 and Tumor Necrosis Factor to Periodontal Tissue Destruction. J. Periodontol. 2003, 74, 391-401. [CrossRef]

81. Armitage, G.C. Periodontal diagnoses and classification of periodontal diseases. Periodontology 2000 2004, 34, 9-21. [CrossRef]

82. Preshaw, P.M.; Taylor, J. How has research into cytokine interactions and their role in driving immune responses impacted our understanding of periodontitis? J. Clin. Periodontol. 2011, 38, 60-84. [CrossRef] [PubMed]

83. Kornman, K.S. Mapping the Pathogenesis of Periodontitis: A New Look. J. Periodontol. 2008, 79, 1560-1568. [CrossRef]

84. Lee, H.-J.; Choi, C.-H. Anti-inflammatory effects of bamboo salt and sodium fluoride in human gingival fibroblasts-An in vitro study. Kaohsiung J. Med. Sci. 2015, 31, 303-308. [CrossRef] [PubMed]

85. Cole, J.B.; Florez, J.C. Genetics of diabetes mellitus and diabetes complications. Nat. Rev. Nephrol. 2020, 16, 377-390. [CrossRef]

86. Preshaw, P.M.; Bissett, S.M. Periodontitis and diabetes. Br. Dent. J. 2019, 227, 577-584. [CrossRef] [PubMed]

87. Pirih, F.Q.; Monajemzadeh, S.; Singh, N.; Sinacola, R.S.; Shin, J.M.; Chen, T.; Fenno, J.C.; Kamarajan, P.; Rickard, A.H.; Travan, S.; et al. Association between metabolic syndrome and periodontitis: The role of lipids, inflammatory cytokines, altered host response, and the microbiome. Periodontology 2000 2021, 87, 50-75. [CrossRef]

88. Tuleta, I.; Frangogiannis, N.G. Diabetic fibrosis. Biochim. Biophys. Acta (BBA)-Mol. Basis Dis. 2020, 1867, 166044. [CrossRef] [PubMed]

89. Shapiro, M.R.; Atkinson, M.A.; Brusko, T.M. Pleiotropic roles of the insulin-like growth factor axis in type 1 diabetes. Curr. Opin. Endocrinol. Diabetes Obes. 2019, 26, 188-194. [CrossRef]

90. Nackiewicz, D.; Dan, M.; Speck, M.; Chow, S.Z.; Chen, Y.-C.; Pospisilik, J.A.; Verchere, C.B.; Ehses, J.A. Islet Macrophages Shift to a Reparative State following Pancreatic Beta-Cell Death and Are a Major Source of Islet Insulin-like Growth Factor-1. iScience 2019, 23, 100775. [CrossRef]

91. Camaya, I.; Mok, T.Y.; Lund, M.; To, J.; Braidy, N.; Robinson, M.W.; Santos, J.; O'Brien, B.; Donnelly, S. The parasite-derived peptide FhHDM-1 activates the PI3K/Akt pathway to prevent cytokine-induced apoptosis of $\beta$-cells. J. Mol. Med. 2021, 99, 1605-1621. [CrossRef]

92. Rachdaoui, N. Insulin: The Friend and the Foe in the Development of Type 2 Diabetes Mellitus. Int. J. Mol. Sci. 2020, 21, 1770. [CrossRef]

93. Yakar, S.; Werner, H.; Rosen, C.J. 40 YEARS OF IGF1: Insulin-like growth factors: Actions on the skeleton. J. Mol. Endocrinol. 2018, 61, T115-T137. [CrossRef]

94. Lee, H.-J.; Arikawa, K. Influence of Low Level Sodium Fluoride on Expression of IGF-1 and IGF-2 Protein in Experimental Type 2 Diabetes with Periodontitis Model. J. Hard Tissue Biol. 2015, 24, 319-324. [CrossRef]

95. Lv, X.-H.; Zhao, D.-H.; Cai, S.-Z.; Luo, S.-Y.; You, T.; Xu, B.-L.; Chen, K. Autophagy plays a protective role in cell death of osteoblasts exposure to lead chloride. Toxicol. Lett. 2015, 239, 131-140. [CrossRef] [PubMed]

96. Yoshii, S.; Kuma, A.; Mizushima, N. Transgenic rescue of Atg5-null mice from neonatal lethality with neuron-specific expression of ATG5: Systemic analysis of adult Atg5-deficient mice. Autophagy 2017, 13, 763-764. [CrossRef] [PubMed]

97. Otomo, C.; Metlagel, Z.; Takaesu, G.; Otomo, T. Structure of the human ATG12 ATG5 conjugate required for LC3 lipidation in autophagy. Nat. Struct. Mol. Biol. 2013, 20, 59-66. [CrossRef] [PubMed]

98. Cheng, Z.; Zhu, Q.; Dee, R.; Opheim, Z.; Mack, C.P.; Cyr, D.M.; Taylor, J.M. Focal Adhesion Kinase-mediated Phosphorylation of Beclin1 Protein Suppresses Cardiomyocyte Autophagy and Initiates Hypertrophic Growth. J. Biol. Chem. 2017, 292, 2065-2079. [CrossRef]

99. Zhang, S.; Niu, Q.; Gao, H.; Ma, R.; Lei, R.; Zhang, C.; Xia, T.; Li, P.; Xu, C.; Wang, C.; et al. Excessive apoptosis and defective autophagy contribute to developmental testicular toxicity induced by fluoride. Environ. Pollut. 2016, 212, 97-104. [CrossRef] [PubMed]

100. Wang, X.; Sato, F.; Tanimoto, K.; Rajeshwaran, N.; Thangavelu, L.; Makishima, M.; Bhawal, U.K. The Potential Roles of Dec1 and Dec2 in Periodontal Inflammation. Int. J. Mol. Sci. 2021, 22, 10349. [CrossRef] [PubMed]

101. Oka, S.; Li, X.; Zhang, F.; Taguchi, C.; Tewari, N.; Kim, I.S.; Zhong, L.; Arikawa, K.; Liu, Y.; Bhawal, U.K. Oral toxicity to high level sodium fluoride causes impairment of autophagy. Res. Sq. 2021, 1-22. [CrossRef] 
102. Anuradha, C.D.; Kanno, S.; Hirano, S. Oxidative damage to mitochondria is a preliminary step to caspase-3 activation in fluoride-induced apoptosis in HL-60 cells. Free. Radic. Biol. Med. 2001, 31, 367-373. [CrossRef]

103. Lee, J.-H.; Jung, J.-Y.; Jeong, Y.-J.; Park, J.-H.; Yang, K.-H.; Choi, N.-K.; Kim, S.-H.; Kim, W.-J. Involvement of both mitochondrialand death receptor-dependent apoptotic pathways regulated by Bcl-2 family in sodium fluoride-induced apoptosis of the human gingival fibroblasts. Toxicology 2008, 243, 340-347. [CrossRef]

104. Suzuki, M.; Bandoski, C.; Bartlett, J.D. Fluoride induces oxidative damage and SIRT1/autophagy through ROS-mediated JNK signaling. Free Radic. Biol. Med. 2015, 89, 369-378. [CrossRef] [PubMed]

105. Chen, Z.; Jin, T.; Lu, Y. AntimiR-30b Inhibits TNF- $\alpha$ Mediated Apoptosis and Attenuated Cartilage Degradation through Enhancing Autophagy. Cell. Physiol. Biochem. 2016, 40, 883-894. [CrossRef] [PubMed]

106. Daiwile, A.; Sivanesan, S.; Izzotti, A.; Bafana, A.; Naoghare, P.K.; Arrigo, P.; Purohit, H.J.; Parmar, D.; Kannan, K. Noncoding RNAs: Possible Players in the Development of Fluorosis. BioMed Res. Int. 2015, 2015, 1-10. [CrossRef]

107. Ouyang, T.; Qin, Y.; Luo, K.; Han, X.; Yu, C.; Zhang, A.; Pan, X. miR-486-3p regulates CyclinD1 and promotes fluoride-induced osteoblast proliferation and activation. Environ. Toxicol. 2021, 36, 1817-1828. [CrossRef] [PubMed]

108. Gao, J.; Qin, Y.; Luo, K.; Wang, X.; Yu, C.; Zhang, A.; Pan, X. Downregulation of miR-4755-5p promotes fluoride-induced osteoblast activation via tageting Cyclin D1. J. Trace Elem. Med. Biol. 2020, 62, 126626. [CrossRef] [PubMed]

109. Jiang, Y.; Yang, Y.; Wang, H.; Darko, G.; Sun, D.; Gao, Y. Identification of miR-200c-3p as a major regulator of SaoS2 cells activation induced by fluoride. Chemosphere 2018, 199, 694-701. [CrossRef] [PubMed]

110. Wang, Y.; Zhang, X.; Zhao, Z.; Xu, H. Preliminary Analysis of MicroRNAs Expression Profiling in MC3T3-E1 Cells Exposed to Fluoride. Biol. Trace Element Res. 2016, 176, 367-373. [CrossRef]

111. Li, C.; Qin, Y.; Ouyang, T.; Yao, M.; Zhang, A.; Luo, P.; Pan, X. miR-122-5p Mediates Fluoride-Induced Osteoblast Activation by Targeting CDK4. Biol. Trace Element Res. 2020, 199, 1215-1227. [CrossRef] [PubMed]

112. Deng, Q.; Yang, J.; Zhouyang, J.; Sheng, W.; Gao, S.; Zhang, Y.; Haopeng, L.; Bingxin, B.; Mengting, W. Preliminary screening of fluorine-stained osteoblastic apoptosis-related microRNA. Anat. Rec. Adv. Integr. Anat. Evol. Biol. 2021, 305, 359-372. [CrossRef] [PubMed]

113. Chen, Q.; Li, Z.; Xu, Z.; Chen, C.; Wang, J.; Zhu, J.; Dong, Z. miR-378d is Involved in the Regulation of Apoptosis and Autophagy of and E2 Secretion from Cultured Ovarian Granular Cells Treated by Sodium Fluoride. Biol. Trace Elem. Res. 2021, 199, 4119-4128. [CrossRef]

114. Sun, Z.; Zhang, W.; Li, S.; Xue, X.; Niu, R.; Shi, L.; Li, B.; Wang, X.; Wang, J. Altered miRNAs expression profiling in sperm of mice induced by fluoride. Chemosphere 2016, 155, 109-114. [CrossRef] [PubMed]

115. Li, Y.; Cheng, M.; Zhao, Y.; Wang, J.; Wang, J. Effects of fluoride on PIWI-interacting RNA expression profiling in testis of mice. Chemosphere 2020, 269, 128727. [CrossRef]

116. Wang, J.; Zhang, Y.; Guo, Z.; Li, R.; Xue, X.; Sun, Z.; Niu, R. Effects of perinatal fluoride exposure on the expressions of miR-124 and miR-132 in hippocampus of mouse pups. Chemosphere 2018, 197, 117-122. [CrossRef]

117. Thylstrup, A.; Fejerskov, O. Textbook of Clinical Cariology, 2nd ed.; Munksgaard: Copenhagen, Denmark, 1994.

118. Silva, M.C.C.; Lima, C.C.B.; Lima, M.D.D.M.D.; Moura, L.D.F.A.D.D.; Tabchoury, C.P.M.; de Moura, M.S. Effect of fluoridated water on dental caries and fluorosis in schoolchildren who use fluoridated dentifrice. Braz. Dent. J. 2021, 32, 75-83. [CrossRef] [PubMed]

119. Manchanda, S.; Sardana, D.; Liu, P.; Lee, G.H.; Li, K.Y.; Lo, E.C.; Yiu, C.K. Topical fluoride to prevent early childhood caries: Systematic review with network meta-analysis. J. Dent. 2021, 116, 103885. [CrossRef]

120. Chaurasiya, A.; Gojanur, S. Evaluation of the clinical efficacy of $38 \%$ silver diamine fluoride in arresting dental caries in primary teeth and its parental acceptance. J. Indian Soc. Pedod. Prev. Dent. 2021, 39, 85-89.

121. Nanda, T.; Jain, S.; Kaur, H.; Kapoor, D.; Nanda, S.; Jain, R. Root conditioning in periodontology—Revisited. J. Nat. Sci. Biol. Med. 2014, 5, 356-358. [CrossRef] [PubMed]

122. Silva, A.C.; Moura, C.C.G.; Ferreira, S.P.B.; De Magalhães, D.; Dechichi, P.; Soares, P.B.F. Biological Effects of a Root Conditioning Treatment on Periodontally Affected Teeth-An In Vitro Analysis. Braz. Dent. J. 2016, 27, 160-168. [CrossRef] [PubMed]

123. Shreehari, A.; Darekar, H.; Borthakur, R. A comparative analysis of root surface biomodification with ethylene diamine tetra acetic acid and tetracycline hydrochloride: An in vitro scanning electron microscopic study. Med. J. Armed Forces India 2016, 72, 145-151. [CrossRef]

124. Andreasen, J.O.; Borum, M.K.; Jacobsen, H.L.; Andreasen, F.M. Replantation of 400 avulsed permanent incisors. 4. Factors related to periodontal ligament healing. Dent. Traumatol. 1995, 11, 76-89. [CrossRef] [PubMed]

125. Hasanuddin, S.; Reddy, J.S. Sequelae of delayed replantation of maxillary permanent incisors after avulsion: A case series with 24-month follow-up and clinical review. J. Indian Soc. Pedod. Prev. Dent. 2018, 36, 410-416. [CrossRef] [PubMed]

126. Sardana, D.; Goyal, A.; Gauba, K. Delayed replantation of avulsed tooth with 15-h extra-oral time: 3-year follow-up. Singap. Dent. J. 2014, 35, 71-76. [CrossRef]

127. Mesquita, G.C.; Soares, P.B.F.; Moura, C.C.G.; Roscoe, M.G.; Paiva, S.M.; Soares, C. A 12-Year Retrospective Study of Avulsion Cases in a Public Brazilian Dental Trauma Service. Braz. Dent. J. 2017, 28, 749-756. [CrossRef] [PubMed]

128. Lauridsen, E.; Andreasen, J.O.; Bouaziz, O.; Andersson, L. Risk of ankylosis of 400 avulsed and replanted human teeth in relation to length of dry storage: A re-evaluation of a long-term clinical study. Dent. Traumatol. 2019, 36, 108-116. [CrossRef] 
129. Kameyama, Y.; Nakane, S.; Maeda, H.; Saito, T.; Konishi, S.; Ito, N. Effect of fluoride on root resorption caused by mechanical injuries of the periodontal soft tissues in rats. Dent. Traumatol. 1994, 10, 210-214. [CrossRef] [PubMed]

130. Foo, M.; Jones, A.; Darendeliler, M.A. Physical properties of root cementum: Part 9. Effect of systemic fluoride intake on root resorption in rats. Am. J. Orthod. Dentofac. Orthop. 2007, 131, 34-43. [CrossRef]

131. Rubin, M.R.; Bilezikian, J.P. New anabolic therapies in osteoporosis. Curr. Opin. Rheumatol. 2002, 14, 433-440. [CrossRef] [PubMed]

132. Mohamed, R.N.; Basha, S.; Al-Thomali, Y.; Alshamrani, A.S.; Alzahrani, F.S.; Enan, E.T. Self-assembling peptide P11-4 in remineralization of enamel caries-A systematic review of in-vitro studies. Acta Odontol. Scand. 2020, 79, 139-146. [CrossRef] [PubMed]

133. Pithon, M.M.; Baião, F.S.; Sant'Anna, L.I.D.; Tanaka, O.M.; Maia, L. Effectiveness of casein phosphopeptide-amorphous calcium phosphate-containing products in the prevention and treatment of white spot lesions in orthodontic patients: A systematic review. J. Investig. Clin. Dent. 2019, 10, e12391. [CrossRef] [PubMed]

134. Butera, A.; Pascadopoli, M.; Gallo, S.; Lelli, M.; Tarterini, F.; Giglia, F.; Scribante, A. SEM/EDS Evaluation of the Mineral Deposition on a Polymeric Composite Resin of a Toothpaste Containing Biomimetic Zn-Carbonate Hydroxyapatite (microRepair ${ }^{\circledR}$ ) in Oral Environment: A Randomized Clinical Trial. Polymers 2021, 13, 2740. [CrossRef] [PubMed] 